\title{
1. International investment law and history: An introduction
}

\section{Stephan W. Schill, Christian J. Tams and Rainer Hofmann}

\section{INTRODUCTION}

The relationship between international investment law and history is ambivalent. On the one hand, the past is very present in current debates, whether they concern standards of treatment, the rationale for international investment law and investor-state arbitration, or future changes and reform. History in that sense clearly matters for investment lawyers: contemporary investment law is the product of historical evolution and, like other fields of international law, is shaped by it. Textbooks (which almost inevitably deal with investment law's history $)^{1}$ reflect that fact, as do scholarly works and arbitral awards that reach back to cases and disputes preceding the emergence of the contemporary system. ${ }^{2}$ On the other hand, more than other fields of international law, investment law is dominated by the 'here and now'. As a relevant discipline, it has emerged relatively recently; many aspects of it are said to be novel; and its every-day practice yields so much new material - treaties, disputes, awards - that it is easy to be all-presentialist.

1 These range from relatively brief tours d'horizon to longer, more comprehensive chapters. For the former see, for example, Rudolf Dolzer and Christoph Schreuer, Principles of International Investment Law (2nd edn, Oxford University Press 2012) 1-9; Krista Nadakavukaren Schefer, International Investment Law: Text, Cases and Materials (2nd edn, Edward Elgar Publishing 2016) 4-11. For the latter see, for example, Andrew Newcombe and Lluís Paradell, Law and Practice of Investment Treaties (Kluwer Law International 2009) 3-57; Kenneth J Vandevelde, Bilateral Investment Treaties (Oxford University Press 2010) 19-74; Jeswald W Salacuse, The Law of Investment Treaties (Oxford University Press 2010) 78-125.

2 For further discussion see below Sections II.A. and II.B. 
Both features - a measure of historical sensitivity, and the dominance of the here and now - may explain how investment lawyers have approached the history of their discipline. Historical arguments feature regularly, but for a long time they mostly seemed to be used instrumentally, and often ornamentally: succinct summaries of broader developments were no doubt useful for didactic purposes; references to age-old precedents helpful to shore up the preferred interpretation of a certain treaty provision (often in order to prevail in a concrete dispute); historical context, as construed, a means to influence the normative and political assessment of substantive and procedural rules included in existing or to-be-negotiated investment agreements. Yet, while commonplace and enriching, and reflecting an awareness of the past's relevance for present debates, such recourse to history was often 'a decidedly instrumental pursuit' ${ }^{3}$ which had little to do with (and did not claim to be) historical scholarship proper. And of course, in their uses of history, investment lawyers as a group were, and are, not immune from the much-decried " "amateurism" of international lawyers' ${ }^{4}$ Indeed, there is sufficient evidence in existing international investment law scholarship of what in the US-American context has been dismissed as 'law office histories' ${ }^{5}$ or 'history "lite" where lawyers "pick and choose facts and incidents ripped out of context that serve their purposes' ${ }^{6}$

For some time, however, change has been underway. In a more recent, burgeoning body of investment law literature, history takes centre stage. The provenance of substantive standards, the background to important treaties, and the establishment of crucial institutions - all these have been studied in much detail, and have prompted book-length inquiries that could hardly be accused of pursuing "history "lite", or of "picking and choosing' facts and incidents at will. ${ }^{7}$ What is more, perhaps reflecting greater awareness of this hitherto 'exotic' branch of international law, ${ }^{8}$

3 David J Bederman, 'Foreign Office International Legal History' in Matthew Craven, Malgosia Fitzmaurice and Maria Vogiatzi (eds), Time, History and International Law (Martinus Nijhoff 2007) 43, 44.

4 Randall Lesaffer, 'International Law and Its History: The Story of an Unrequited Love' in Craven et al (n 3) 33, 35.

5 For comment, see Bederman (n 3) 44.

6 Martin Flaherty, 'History "Lite" in Modern American Constitutionalism' (1995) 95 Columbia Law Review 523, 553.

7 For examples see below Section II.B.

8 For this qualification, see Martti Koskenniemi, 'Fragmentation of International Law: Difficulties Arising from the Diversification and Expansion of International Law', Report of the Study Group of the International Law Commission, UN Doc A/CN.4/L.682, para 8. 
historians and social scientists are slowly beginning to enter the field. ${ }^{9}$ With little delay, international investment law now seems to be participating in the 'turn to history' that characterizes international legal scholarship at large since the beginning of the 21 st century. ${ }^{10}$

The trend is at an early stage though, the turn just about to begin. Recent book-length analyses offer in-depth accounts, but they remain narrowly focused (in the grander scheme of things) on core themes of legal analysis - concepts, institutions and the like. What is more, while scholars have begun to focus on the past, the recent turn to history in international investment law has yet to yield serious reflections within the discipline as a whole on the benefits and challenges of historical research for the understanding of this field of law and practice.

All this forms the background to the present book. Proceeding from the (generally shared) assumption that history matters and drawing on the recent trend towards a fuller engagement, it seeks to consolidate the turn

9 See, for example, Noel Maurer, The Empire Trap: The Rise and Fall of U.S. Intervention to Protect American Property Overseas, 1893-2013 (Princeton University Press 2013); Lauge N Skovgaard Poulsen, Bounded Rationality and Economic Diplomacy: The Politics of Investment Treaties in Developing Countries (Cambridge University Press 2015).

10 Significant works include Martti Koskenniemi, The Gentle Civilizer of Nations (Cambridge University Press 2001); Ram Prakash Anand, Studies in International Law and History: An Asian Perspective (Martinus Nijhoff 2004); Emmanuelle Jouannet, Le droit international libéral-providence: une histoire du droit international (Bruxelles 2011); Arnulf Becker Lorca, Mestizo International Law: A Global Intellectual History 1842-1933 (Cambridge University Press 2014); as well as the following edited volumes: Craven et al (n 3); Alexander Orakhelashvili (ed), Research Handbook on the Theory and History of International Law (Edward Elgar Publishing 2011); Bardo Fassbender and Anne Peters (eds), The Oxford Handbook of the History of International Law (Oxford University Press 2012); Pierre-Marie Dupuy and Vincent Chetail (eds), The Roots of International Law / Les fondements du droit international: Liber Amicorum Peter Haggenmacher (Brill 2014). For a fuller bibliographical survey, see Frederik Dhondt, 'Recent Research in the History of International Law' (2016) 84 Tijdschrift voor Rechtsgeschiedenis 313. For overarching perspectives see also George RB Galindo, 'Martti Koskenniemi and the Historiographical Turn in International Law' (2005) 16 European Journal of International Law 539; Matthew Craven, 'Theorizing the Turn to History in International Law' in Anne Orford and Florian Hoffmann (eds), The Oxford Handbook of the Theory of International Law (Oxford University Press 2016) 21; and Valentina Vadi, 'International Law and Its Histories: Methodological Risks and Opportunities' (2017) 58 Harvard International Law Journal (forthcoming) <www.research. lancs.ac.uk/portal/services/downloadRegister/156805959/Histories_Harvard_Vadi. pdf $>$ accessed 30 August 2017. 
to history in international investment law. To that end, it brings together a broad range of historical inquiries, which not only seek to advance our understanding of historical developments, but also to reflect on the potential contribution of historical research to a better understanding of international investment law itself. The book does not present to the reader 'the' history, or even 'a' (more of less comprehensive) history, of international investment law. Instead, through a series of studies, it analyses the preconditions, methodological possibilities, benefits, and challenges of engaging in historical research and historical argument in the field. What it offers, in other words, is an ouverture that illustrates how a consolidated turn to history could enrich the discipline of international investment law.

This introductory chapter sets the stage. Part II describes the status quo. It illustrates the openness of investment lawyers to historical argument and retraces the beginning of the turn to history in recent writings. As this trend remains tentative and cautious, Part III sketches out potential avenues for future research and indicates how international investment law could benefit from a fuller engagement with history. Part IV illustrates the benefits of such a fuller approach by situating the contributions to the present book. Part V concludes by suggesting that historical approaches to international investment law could not only enrich this specialized field of international law. Instead, a 'turn to history' in international investment law could also stimulate the interest of international legal historiography in international economic law and the economic foundations of international law.

\section{INVESTMENT LAW AND HISTORY: THE STATUS QUO}

The turn to history, that is, a more reflective engagement with history, that we observe as of recent in international investment law has not developed from scratch. It builds on a long-standing sensitivity in practice and scholarship of the history of the field. The subsequent sections assess this status quo by identifying uses of history in contemporary investment law. The treatment is selective, but it hopefully succeeds in portraying a discipline that has been historically sensitive for a long time, and is now beginning to view its past as a subject of in-depth study. Reflecting the dominance of investment dispute settlement, the section begins by surveying historical argumentations in arbitral awards (A.). It then situates significant academic contributions that mark the start of the recent turn to history in investment law scholarship (B.). 


\section{A. Historical Arguments in Investor-State Dispute Settlement}

Of the various features making up contemporary investment law, investor-state dispute settlement has the most obvious claim to novelty. In the words of one commentator, 'it was only in 1990 that the defining feature of FIL [that is, foreign investment law] - private standing to invoke treaty breach - materialized'. ${ }^{11}$ Even this fledgling branch of arbitration is sensitive to its history though. Widely read newsletters now feature short entries, entitled 'Looking Back', which revisit 'historic' investment treaty arbitrations starting from 25 years back; ${ }^{12}$ the Institute for Transnational Arbitration seeks to preserve an 'oral history' of international arbitration, including investment arbitration, through interviews of present-day arbitration practitioners; ${ }^{13}$ and the International Council for Commercial Arbitration (ICCA) compiles 'historic documents' relating to international commercial and investment arbitrations. ${ }^{14}$

Beyond these initiatives, it is worth noting that historical arguments regularly play an important role in a significant number of investor-state arbitrations. Notably, tribunals recurringly rely on old case law as guidance, or persuasive precedent, for the interpretation and application of rules governing the dispute before them. As the subsequent survey suggests, this use of historical argument is extremely common and assists in the construction of substantive investment treaty standards as well as the solution of questions of jurisdiction and procedure.

11 Joost Pauwelyn, 'At the Edge of Chaos? Foreign Investment Law as a Complex Adaptive System, How It Emerged and How It Can Be Reformed' (2014) 29 ICSID Review 372, 400. See also Jan Paulsson, 'Arbitration Without Privity' (1995) 10 ICSID Review 232, 256 (describing investment arbitration as something 'dramatically different from anything previously known in the international sphere').

12 For the first such feature see Joel Dahlquist and Luke Eric Peterson, 'Looking Back: In First Known Treaty-Based Investor-State Arbitration, AAPL v. Sri Lanka, Tribunal Saw a Failure to Protect Investment That Was Overrun During Counter-Insurgency' IAReporter, 15 January 2017 <www.iareporter.com/ articles/looking-back-in-first-known-treaty-based-investor-state-arbitration-aaplv-sri-lanka-tribunal-saw-a-failure-to-protect-investment-that-was-overrun-duringcounter-insurgency/> accessed 30 August 2017.

13 See Institute for Transnational Arbitration, 'Preserving Perspectives: International Arbitrators in Their Own Words' < https://vimeopro.com/user34174610/ ita-oral-history-interviews> accessed 30 August 2017.

14 See International Council for Commercial Arbitration, 'Historic Documents in Arbitration' <www.arbitration-icca.org/historic-treasures/historic_documents. html $>$ accessed 30 August 2017. 
References to pre-World War II case law were prominent already in the first ever investment treaty arbitration in AAPL v. Sri Lanka. Here, the Tribunal made numerous references to historical cases, either directly or via the secondary literature digesting them. ${ }^{15}$ These references served several purposes. Thus, to determine the content of the rules of interpretation under Article 31 of the Vienna Convention on the Law of Treaties and its application to the United Kingdom-Sri Lanka Bilateral Investment Treaty (BIT), the Tribunal referred to awards of the early 20th century Mixed Claims Commission, including those established between Germany and Venezuela, the United States and Venezuela, the United States and Mexico, Bulgaria and Greece, Germany and the United States, and France and Mexico. ${ }^{16}$

Similarly, in order to interpret substantive standards of treatment, specifically the full protection and security clause in the United KingdomSri Lanka BIT, the Tribunal in AAPL v. Sri Lanka invoked, amongst others, cases decided by the Italy-Venezuela Mixed Claims Commission, the Netherlands-Venezuela Mixed Claims Commission, the GermanyVenezuela Mixed Claims Commission, and the Mexico-United States General Claims Commission rendered between 1900 and 1940. ${ }^{17}$ Furthermore, rules on evidence were expounded, inter alia, through reference to decisions of the Spain-Venezuela Mixed Claims Commission and the Mexico-United States General Claims Commission. ${ }^{18}$ Moreover, it is worth noting that, in addition to consulting historical cases, the Tribunal several times invoked Emer de Vattel as an authority on points of international (investment) law. ${ }^{19}$ The Tribunal in AAPL v. Sri Lanka therefore had a clear sense of being part of a long-held tradition of international dispute settlement that it was to carry forward.

Although few subsequent investment treaty arbitrations have involved a comparable amount of historical references, pre-World War II cases appear in arbitral awards in a recurring fashion. The Neer award, decided in 1926 by the Mexico-United States General Claims Commission, ${ }^{20}$ is a particular case in point. In it, the Commission offered a formula to assess

15 Chief among them was Bin Cheng, General Principles of Law as Applied by International Courts and Tribunals (Stevens 1953).

16 See AAPL v Sri Lanka, ICSID Case No ARB/87/3, Award (27 June 1990) paras 38-40.

17 ibid paras 47-48, 53, 63, 74, 75 .

18 ibid para 56.

19 ibid paras 40 and 65.

20 LFH Neer and Pauline Neer (United States of America) $v$ United Mexican States, Award (15 October 1926) (1926) 4 RIAA 60. 
violations of the customary international minimum standard in respect of the treatment of aliens. It held that

the treatment of an alien, in order to constitute an international delinquency, should amount to an outrage, to bad faith, to wilful neglect of duty, or to an insufficiency of governmental action so far short of international standards that every reasonable and impartial man would readily recognize its insufficiency. ${ }^{21}$

For years, tribunals (most notably, but not exclusively, in the context of the North American Free Trade Agreement (NAFTA)) have discussed whether this formula is still an accurate reflection of the state of customary international law, and, if so, how that customary standard relates to the fair and equitable treatment (FET) standard contained in modern investment treaties.

While tribunals have adopted different views on these questions, discussions of the Neer case figure prominently in the parties' pleadings and the tribunals' decisions in numerous NAFTA Chapter 11 arbitrations. ${ }^{22}$ The approach of the Tribunal in Glamis Gold v. United States ${ }^{23}-$ though contested in subsequent $\operatorname{cases}^{24}$ - placed particular weight on this historical case for the interpretation of contemporary treaty standards, such as Article 1105 NAFTA: it concluded that the Neer case and the standard expressed therein remained the point of departure for determining the content of the customary international law minimum standard and that it was for the party invoking an evolution of that standard to prove it. ${ }^{25}$ As the Glamis tribunal itself recognized, such an approach 'because of the difficulty in proving a change in custom, effectively freezes the protections provided for in this provision at the 1926 conception of egregiousness'.26

21 ibid 61-62.

22 See Patrick Dumberry, The Fair and Equitable Treatment Standard (Kluwer Law International 2013) 16-19, 106-124 (discussing the pertinent case law under NAFTA). See also Bilcon of Delaware Inc et al v Canada, UNCITRAL, PCA Case No 2009-04, Award on Jurisdiction and Liability (17 March 2015) paras 427-445; Mesa Power Group LLC v Canada, UNCITRAL, PCA Case No 2012-17, Award (24 March 2016) paras 496-507.

23 See Glamis Gold Ltd $v$ United States, UNCITRAL/NAFTA, Award (8 June 2009).

24 See in particular Merrill \& Ring Forestry LP v Canada, UNCITRAL/ NAFTA, Award (31 March 2010) paras 195-213.

25 See Glamis Gold (n 23) paras 600-616.

26 ibid para 604. 
The approach in Glamis, and perhaps the debate under NAFTA more generally, is a particular form of doctrinal perspective. But the willingness of arbitral tribunals to engage with old case law is not. Whether established under NAFTA or another investment treaty, tribunals regularly turn to historical cases to support their construction of substantive standards of treatment. ${ }^{27}$

Tribunals also seek guidance from old case law in dealing with questions of arbitral procedure and jurisdiction. The ad hoc Committee in Soufraki v. United Arab Emirates, for example, invoked cases from the 19th and early 20th century Mixed Claims Commission between the United States and Costa Rica, Great Britain, Mexico, France, Spain and Venezuela, respectively, to support its view that international tribunals were empowered to assess questions of nationality, without being bound by certificates of nationality or naturalization. ${ }^{28}$ On the issue of jurisdiction, several tribunals relied on pre-World War II decisions to assess the effect of contractual forum selection clauses on claims for breaches of international law. ${ }^{29}$

27 See Adel A Hamadi Al Tamimi v Sultanate of Oman, ICSID Case No. ARB/11/33, Award (3 November 2015) para 383 (referencing the Neer case); Ol European Group BV v Venezuela, ICSID Case No ARB/11/25, Award (10 March 2015) paras 486-489 (referencing the 1926 Roberts case of the MexicoUnited States General Claims Commission as an expression of the minimum standard of treatment); Joseph C Lemire v Ukraine, ICSID Case No ARB/06/18, Decision on Jurisdiction and Liability (21 January 2010) paras 248-249 (likewise); Biwater Gauff (Tanzania) Ltd. v. United Republic of Tanzania, ICSID Case No ARB/05/22, Award (24 July 2008) para 505 (invoking the 1930 Lena Goldfields arbitration as precedent on expropriation); Swisslion DOO Skopje $v$ The Former Yugoslav Republic of Macedonia, ICSID Case No ARB/09/16, Award (6 July 2012) fn 328 (referencing the 1927 Chattin case of the MexicoUnited States General Claims Commission '[f]or an in depth analysis of the concept of denial of justice').

28 Hussein Nuaman Soufraki $v$ The United Arab Emirates, ICSID Case No. ARB/02/7, Decision of the Ad Hoc Committee on the Application for Annulment of Mr. Soufraki (5 June 2007) paras 66-70 (see also ibid paras 107-111 where the Committee relied, inter alia, on precedent by the Mexico-United States General Claims Commission to determine what law governed questions of procedure for determining nationality). See also Methanex Corporation v. United States of America, UNCITRAL, Decision of the Tribunal on Petitions from Third Persons to Intervene as 'amici curiae' (15 January 2001) para 44 (pointing to the publication of the arbitral award in the 1930 Lena Goldfields arbitration to suggest that English law on arbitration had not traditionally adopted a strict approach to confidentiality in earlier times).

29 Compañiá de Aguas del Aconquija S.A. and Vivendi Universal S.A. $v$ Argentine Republic (formerly Compañía de Aguas del Aconquija, S.A. and 
These examples are illustrative only. They highlight the most prominent use of history in investment arbitration: tribunals turn to the past for guidance on the construction of contemporary investment law. As the preceding summary indicates, historical arguments are common, and at times determinative, in the present-day practice of investor-state dispute settlement.

\section{B. The Turn to History in Investment Law Literature}

Perhaps more than in awards, historical sensitivity comes to the fore in the writings on international investment law. This is not only the case, as noted in the introductory section, with many of the most widely used investment law textbooks. ${ }^{30}$ Also in more targeted analyses, the origins and evolution of issues of contemporary investment law remain a popular topic. ${ }^{31}$ In line with the discipline's focus on disputes and cases, new perspectives on old landmark decisions remain a particularly prominent sub-genre of historically informed scholarship in international investment law. ${ }^{32}$ All this reflects an openness towards history, on which the more

Compagnie Générale des Eaux v Argentine Republic), ICSID Case No. ARB/ 97/3, Decision on Annulment (3 July 2002) paras 98-100; SGS Société Générale de Surveillance S.A. v Republic of the Philippines, ICSID Case No ARB/02/6, Decision of the Tribunal on Objections to Jurisdiction (29 January 2004) paras $150-152$.

30 See above $\mathrm{n} 1$ and the sources listed therein.

31 See, for example, Tom Johnson and Jonathan Gimblett, 'From Gunboats to BITs: The Evolution of Modern International Investment Law' in Karl Sauvant (ed), Yearbook on International Investment Law and Policy 2010-2011 (Oxford University Press 2012) 649; Leon E Trakman and Nicola W Ranieri, 'Foreign Direct Investment: A Historical Perspective' in Leon E Trakman and Nicola W Ranieri (eds), Regionalism in International Investment Law (Oxford University Press 2013) 14; Ahmad Ali Ghouri, 'The Evolution of Bilateral Investment Treaties, Investment Treaty Arbitration and International Investment Law' (2011) 14(6) International Arbitration Law Review 189; Kenneth J Vandevelde, 'A Brief History of International Investment Agreements' (2005) 12 UC Davis Journal of International Law and Policy 157; Stephan W Schill, The Multilateralization of International Investment Law (Cambridge University Press 2009) 23-64; Santiago Montt, State Liability in Investment Treaty Arbitration (Hart 2009) 31-74.

32 See, for example, VV Veeder, 'The Lena Goldfields Arbitration: The Historical Roots of Three Ideas' (1998) 47 International \& Comparative Law Quarterly 747; Stephen D Fitch, 'The Harriman Manganese Concession in the Soviet Union: Lessons for Today' (1991) 9 Berkeley Journal of International Law 209; Michael Reynolds, 'The Jaffa Jerusalem Railway Company Arbitration 1922' (1991) 6 Arab Law Quarterly 215; Shabtai Rosenne, 'The Jaffa-Jerusalem 
recent literature that embraces historical arguments has built. Of particular note, in this context, are a number of recent book-length studies that draw on historical insights to elucidate the state of investment law as it currently stands and to understand the emergence of institutions, the role of specific states in the development of investment law, and the biases that have shaped, and are being shaped by the field's history.

The role of history and historical argument for the doctrine of investment law is explored in a number of studies. Jan Paulsson's book Denial of Justice in International Law, published in 2005, analyses the concept of denial of justice as a present-day cause of action under international law, in particular as it relates to human rights and foreign investment law. ${ }^{33}$ Responding to the lack of doctrinal clarity in the application of the concept in modern investment treaty arbitration, Paulsson looks towards history as a source of international law. Thus, in order to construct the contours and contents of the denial-of-justice concept, he turns to an analysis of gunboat diplomacy and arbitral case law in the 19th and early 20th century, the emergence of the Calvo Doctrine, and the heated post-World War II debates about substantive and procedural protection of foreign investors. ${ }^{34}$ Yet, Paulsson's analysis of history is not limited to doctrinal (re-)construction. Pointing to 'hundreds of such cases in the nineteenth century,' he also uses history as an argument to respond to critics of investment law and arbitration. After all,

Railway Arbitration (1922)' (1998) 28 Israel Yearbook on Human Rights 239; VV Veeder, 'Lloyd George, Lenin and Cannibals: The Harriman Arbitration The 1999 Freshfields Lecture' (2000) 16 Arbitration International 115; VV Veeder, 'The Historical Keystone to International Arbitration: The PartyAppointed Arbitrator - From Miami to Geneva' in David D Caron et al (eds), Practising Virtue: Inside International Arbitration (Oxford University Press 2015) 127; Oscar Garibaldi, 'Jurisdictional Errors: A Critique of the North American Dredging Company Case' in Caron et al, ibid at 167; VV Veeder, 'Chancellor Wirth and the Mologales Concession 1923-1927: The GermanSpeaking Origins of the 1965 ICSID Convention' in Christina Binder et al (eds), International Investment Law for the 21st Century: Essays in Honour of Christoph Scheuer (Oxford University Press 2009) 377; Jason Webb Yackee, 'The First Investor-State Arbitration: The Suez Canal Company v Egypt (1864)' (2016) 17 The Journal of World Investment \& Trade 401. See also the contributions in Ulf Franke et al (eds), Arbitrating for Peace (Kluwer Law International 2016). For a listing of investor-state arbitrations in the 19th and 20th centuries see also AM Stuyt (ed), Survey of International Arbitrations: 1794-1989 (Martinus Nijhoff 1990) 471-561.

33 Jan Paulsson, Denial of Justice in International Law (Cambridge University Press 2005).

34 Paulsson's doctrinal argument is laid out in chs 2-8. 
'[t]he proposition that states may be held accountable under international law by arbitral tribunals created by treaty is neither new nor radical'.$^{35}$

An approach to develop doctrine for present-day investment law through recourse to historical analysis is also taken by Martins Paparinskis in his 2013 monograph The International Minimum Standard and Fair and Equitable Treatment. ${ }^{36}$ Seeking to clarify the meaning of the often tersely worded and ambiguous notion of FET, Paparinskis' approach is to further our understanding of the treaty standard through an understanding of the customary international law minimum standard. ${ }^{37}$ This standard can, in turn, be reconstructed (as Paparinskis shows in a detailed and meticulous fashion) through historical analysis of, inter alia, the voluminous case law of the inter-war claims commissions, the inter-war debates on protection of property under international law, and the work of the International Law Commission on state responsibility after World War II. ${ }^{38}$ Paparinskis goes on to argue that, once the content of customary law is clarified through this (historical) method, it can and should influence the interpretation of treaty-based norms on FET. ${ }^{39}$ Through this source-based approach, historical analysis of diplomatic, dispute settlement, and scholarly practice, becomes directly relevant for the construction of the content of investment treaty standards.

Historical analysis is also the principal focus of Todd Weiler's 2013 study, The Interpretation of International Investment Law. ${ }^{40}$ Discussing a broader set of investment treaty standards than Paulsson and Paparinskis, including FET, full protection and security, and rules on nondiscrimination, Weiler sets out 'to demonstrate how historical analysis can be applied in the construction of certain key international investment law obligations' ${ }^{41}$ In his view, historical analysis is not only useful for the clarification of the vague treaty standards in question, it is also indispensable, since 'anyone who attempts to interpret the provisions of

\footnotetext{
35 ibid 261.

36 Martins Paparinskis, The International Minimum Standard and Fair and Equitable Treatment (Oxford University Press 2013).

37 For a summary of his argument see ibid 'Introduction'.

38 This is done mainly in ibid chs $1-3$.

39 See ibid chs 5-6.

40 Todd Weiler, The Interpretation of International Investment Law: Equality, Discrimination and Minimum Standards of Treatment in Historical Context (Martinus Nijhoff 2013).

41 ibid xli.
} 
an investment treaty, without first establishing a proper historical grounding, risks embarking upon a rudderless excursion in subjective analysis'. ${ }^{42}$ From this point of departure, Weiler delves into demonstrating that a number of propositions in the contemporary construction of investment treaty standards are 'historically unsound' 43 and should either be corrected in light of their history or debunked as political agendas pursued by the respective advocate-interpreter. Unlike Paulsson and Paparinskis, Weiler's principal focus is on the history of ideas, rather than diplomatic or dispute settlement practice, as it developed both in European and non-European thought on the international law governing the relations between foreigners and sovereigns. ${ }^{44}$ His key concern, however, is similar to that of the two other authors, namely to influence the present-day practice of investment law and dispute resolution.

The role of actors and institutions in the history of international investment law is another topic that has attracted attention in recent book-length studies. In 2012, Antonio Parra presented a historical analysis of the creation of the International Centre for Settlement of Investment Disputes (ICSID) in The History of ICSID. ${ }^{45}$ Unlike the books discussed earlier, Parra does not focus on substantive investment law; instead, his aim is to write 'an overall history of the institution and its constituent treaty'. ${ }^{46}$ His analysis, based on a detailed study of historical documents embedded 'in their broader political, economic and, above all, institutional context', ${ }^{47}$ explains how the idea for a dispute settlement institution was born at the World Bank and what steps were taken to successfully mold the Convention on the Settlement of Investment Disputes between States and Nationals of Other States (ICSID Convention) in a politically difficult climate in the 1960s and put ICSID into operation. ${ }^{48}$ Yet, Parra's study does not stop there; it continues to

42 ibid 1.

43 ibid 17.

44 Weiler deals with, for example, the classical European thinkers on international law, such as Grotius, Gentilli, Suárez, Hobbes and Pufendorf, but also religious and philosophical texts from the Buddhist, Jewish and Islamic traditions, as well as the principles applicable to the treatment of foreigners throughout ancient and medieval history, the Age of Enlightenment, all the way through to the 19th and 20th centuries. See ibid 59-128. Furthermore, experiences outside Europe are addressed, such as those of Native American nations and China during the 19th century. See ibid 130-158.

45 Antonio R Parra, The History of ICSID (Oxford University Press 2012).

46 ibid 1.

47 ibid.

48 See ibid chs 2-6. 
trace ICSID's institutional evolution over the next five decades, merging directly into the present debates about institutional adaptation and reform. ${ }^{49}$ His analysis therefore enhances our understanding of both the institution's history and its current challenges.

Not only the role of investment law's institutions forms part of historical analysis; also, the role of specific states in the evolution of investment law and policy is starting to be explored from a historical perspective. Kenneth J Vandevelde's 2017 book, The First Bilateral Investment Treaties: U.S. Postwar Friendship, Commerce, and Navigation Treaties, ${ }^{50}$ is part of this trend. It assesses how and why the United States, soon after World War II, developed its age-old friendship, commerce and navigation (FCN) treaty programme into an instrument that did not only concern the establishment of trade and maritime relations, but also granted constitution-like protections to foreign investors. Vandevelde's study, which is based on an analysis of a great number of primary sources relating to the negotiation of US FCN treaties after World War II, ${ }^{51}$ offers important insights for the debate surrounding the origins and objectives of modern international investment law. Thus, Vandevelde argues that the renewed US FCN programme after World War II took the New Deal as a model to govern the global economy in order to create prosperity and lasting peace as an antidote to both the Great Depression and World War II, influencing not only US, but investment treaty practice globally. ${ }^{52}$ Furthermore, his study questions the prominent view that sees the origins of modern investment law in the BIT programmes of European states based on the 1959 Abs-Shawcross Draft Convention on Investments Abroad and instead presents the US FCN programme as the 'birthing moment' 53 of international investment law.

Finally, Kate Miles' study on The Origins of International Investment Law: Empire, Environment and the Safeguarding of Capital, published in

49 ibid chs 7-10.

50 Kenneth J Vandevelde, The First Bilateral Investment Treaties: U.S. Postwar Friendship, Commerce, and Navigation Treaties (Oxford University Press 2017).

51 For an overview of the sources drawn on, see ibid 7-9.

52 For a concise summary of that argument, see ibid 1-5; for further elaboration on the underlying ideology of the US treaty programme see ibid $11-28$.

53 ibid 1. 
2013, stands out for its critical perspective on the discipline and its history. ${ }^{54}$ Its focus is neither on doctrinal questions nor on institutional history. Instead, Miles presents an analysis of the history of international investment law as 'deeply embedded within the global expansion of European trading and investment activities'55 in Africa, Latin America and Asia. Although committed on its face to universal and neutral principles, the law that emerged was, Miles argues, one-sided in favour of capital-exporting states, projecting and putting into operation imperial and hegemonic notions of international law. ${ }^{56}$ The historically developed one-sidedness, Miles shows by using the treatment of environmental concerns as an example, is still present in the law as it stands today, ${ }^{57}$ but could be overcome in the current reform debate.58 Miles' historical analysis, which is focused on the emergence of the structures of contemporary law, stands in the tradition of critical legal studies and Third World Approaches to International Law (TWAIL). Historical analysis, in that context, serves not primarily as an instrument to clarify the doctrinal operations of the regime, but to expose the power structures underlying it in order to reach a more emancipated state of the law in the future.

Like the brief survey of historically informed arbitral awards, so this review of recent literature is illustrative only. It suggests that historical inquiries are assuming a more prominent place in investment law scholarship, and highlights particularly common strands of the emerging turn to history.

\section{WHERE TO GO FROM HERE? CONSOLIDATING THE TURN TO HISTORY}

The preceding survey reflects a considerable measure of awareness among investment lawyers that history matters to their discipline. At the same time, it suggests that, so far, only very selected aspects of this history have been explored - and by a very select group of writers: by and large, the history of investment law to date remains a scholarly

54 Kate Miles, The Origins of International Investment Law: Empire, Environment and the Safeguarding of Capital (Cambridge University Press 2013).

55 ibid 2.

56 See ibid chs 1 and 2.

57 See ibid chs 3 and 4.

58 See ibid chs 5 and 6. 
pursuit of individual investment lawyers, often those with practical leanings. This in turn may explain the dominance of studies focusing on core legal concepts, their interpretation and application (Paparinskis, Paulsson, Weiler), institutions and actors (Parra, Vandevelde), and the spirit in which critical accounts (such as Miles') are written.

None of this is a bad thing; in fact, it may be only natural that, in technical and specialized fields, such as international investment law, disciplinary specialists lead the turn to history. What is more, their dominance, and the focus on core legal concepts and institutions, may be no more than a temporary phenomenon. If experience with public international law more generally is any guide, the turn to history there, once it has gathered momentum, is likely over time to result in a fuller, and more diverse, analysis, one that frees scholarship from doctrinal legal constraints and opens up new avenues of research. The preceding summary of historical studies suggests that this diversification has yet to reach investment law scholarship.

However, investment lawyers could certainly benefit from the longstanding debates about the role of historical scholarship in public international law ${ }^{59}$ and the methodological challenges it entails: not because research in international investment law necessarily has to follow the trajectory of historical research conducted in other fields of international law, but because debates prompted by the historiographical turn yield crucial lessons about the potential impact, limits and preconditions of historical inquiries not only for general international law, but for any more specific area of international law as well. Three lessons, in our view, are particularly important and should guide future research into the history of international investment law. They include a broadening of historical inquiry (A.), attention to the sources of historical research (B.), and generally more reflection on the use and role of historical analysis in international investment law (C.).

\section{A. Broader Focus: Manifold Ways of Doing History}

A first lesson concerns the objects and trajectories of historical inquiries. As is clear from the preceding summary, much of the existing historical research in international investment law is driven by what is doctrinally relevant, and takes the form of a history of ideas (Ideengeschichte), notably focusing on ideas that have been translated into legal concepts, principles and rules. The history of legal concepts - a particular version

59 For references to works of significance see above n 10 . 
of what German historical scholars might view as 'conceptual history' (Begriffsgeschichte $)^{60}$ - no doubt remains crucial; it remains an important aspect of legal history simply because principles and rules of law tend to be based on concepts. ${ }^{61}$

But 'history can be written in many modes or forms';62 and historiographical turns in other fields of international law have prompted scholars to make use of a much broader range of inquiries. The "history of events' is a well-established sub-genre that has resulted in influential studies evaluating key moments in the development of international law. These in turn can be studied in different ways, from the sweeping overall (macro-)account 'seek[ing] out large, long-term trends', ${ }^{63}$ to the most minutely detailed account ('micro-history'). ${ }^{64}$ Whatever the scale, traditional inquiries often centered on major political developments - peace treaties, the setting up of international organizations, the landmark cases, etc. - and these have greatly advanced our understanding of how international law has been shaped. ${ }^{65}$

60 See Reinhard Koselleck, The Practice of Conceptual History: Timing History, Spacing Concepts (Stanford University Press 2002 - transl Todd Samuel Presler).

61 See Bardo Fassbender and Anne Peters, 'Introduction: Towards a Global History of International Law' in Fassbender and Peters (n 10) 1, 13.

62 ibid 11.

63 Vadi (n 10) 18. The early standard texts tended to be of such (macro-) character: see, for example, Wilhelm G Grewe, Epochen der Völkerrechtsgeschichte (Nomos 1984) (translated by Michael Byers as The Epochs of International Law (de Gruyter 2000)); Arthur Nussbaum, A Concise History of the Law of Nations (Macmillan 1947); and more recently Stephen C Neff, Justice Among Nations - A History of International Law (Harvard University Press 2014).

64 See Giovanni Levi, 'On Microhistory' in Peter Burke (ed), New Perspectives on Historical Writing (Polity 1991) 93-113; Carlo Ginzburg et al, 'MicroHistory: Two or Three Things That I Know About It' (1993) 20 Critical Inquiry 10. Cf Vadi (n 10) 18-19.

65 Pars pro toto see the abundant scholarship on the Peace of Westphalia (part of which has sought to question the mythical relevance accorded to the two treaties). See Bardo Fassbender, 'Westphalia, Peace of' in Rüdiger Wolfrum (ed), Max Planck Encyclopaedia of Public International Law (online edition) <www.mpepil.com> accessed 30 August 2017; Arthur Eyffinger, 'Europe in the Balance: An Appraisal of the Westphalian System' (1998) 45 Netherlands International Law Review 161; O Moorman van Kappen (ed), Renegotiating Westphalia: Essays and Commentary on the European and Conceptual Foundations of Modern International Law (Kluwer 1999); Stéphane Beaulac, 'The Westphalian Legal Orthodoxy - Myth or Reality?' (2000) 2 Journal of the 
While the gravitational pull of the major events remains strong, historically informed scholarship has moved beyond them, assessed 'the force of international law' in lesser 'events', and raised awareness of international law 'stories' beyond the limelight. 66 Perhaps concomitantly, the grand narratives à la Grewe ${ }^{67}$ are complemented, and increasingly replaced, by micro-histories that ' $\min [\mathrm{e}]$ small episodes, often discovered serendipitously, for insights into major themes of international legal history' ${ }^{68}$ While much work remains to be done, islands of in-depth knowledge have appeared in the sea of international legal history; and the historical context of international law begins to emerge more clearly.

Beyond events, the historiographical turn in public international law has sparked interest in the role of protagonists. Biographical studies have clear limits (as they risk reducing developments to the 'history of great men and women'), ${ }^{69}$ but have become a key feature of recent international legal scholarship and greatly deepened our understanding of the

History of International Law 148; Derek Croxton, 'The Peace of Westphalia of 1648 and the Origins of Sovereignty' (1999) 21 The International History Review 569; Randall Lesaffer, 'The Westphalian Peace Treaties and the Development of the Tradition of Great European Peace Settlements Prior to 1648' (1997) 18 Grotiana 71; Andreas Osiander, 'Sovereignty, International Relations and the Westphalian Myth' (2001) 55 International Organization 251; Karl-Heinz Ziegler, 'Die Bedeutung des Westfälischen Friedens von 1648 für das europäische Völkerrecht' (1999) 37 Archiv des Völkerrechts 129.

66 Cf Fleur Johns et al (eds), Events: The Force of International Law (Routledge 2011); John E Noyes et al (eds), International Law Stories (Foundation Press 2007). For select examples see, for example, Genevieve Renard Painter, 'A Letter from the Haudenosaunee Confederacy to King George V: Writing and Reading Jurisdictions in International Legal History' (2017) 5 London Review of International Law 7; Richard P Boast, 'The Waitangi Tribunal in the Context of New Zealand's Political Culture and Historiography' (2016) 18 Journal of the History of International Law 339; Nathaniel Berman, Passion and Ambivalence: Colonialism, Nationalism and International Law (Brill 2011).

67 See Grewe (n 63).

68 Vadi (n 10) 18.

69 See Galindo (n 10) 543 (discussing Koskenniemi's concern that 'biographical research on international lawyers [might] ... emphasiz[e] the role of a handful of great minds without giving due attention to the external factors which invariably influenced the work of those authors'). Nevertheless, the basic claim remains that 'we cannot fully understand the nature and functioning of any human group without knowing about the individuals who compose it. This knowledge must come from biographies'; see JE Neale, 'The Biographical Approach to History' (October 1951) 36:128 History 194, 196. 
personal dimension of the history of international law. ${ }^{70}$ The alleged 'fathers' of the discipline continue to command attention, including by biographers; but recent scholarship emphasizes the need to look beyond Grotius and Vattel; for example, by underlining the influence of LatinAmerican or Asian scholars ${ }^{71}$ and focusing attention on scholars straddling jurisdictional and cultural divides. ${ }^{72}$ And of course, the most successful studies combine elements of the different approaches; for example, by 'intertwin[ing] biographical and contextual (epochal) elements as part of a narrative history of the profession and its ideas'. ${ }^{73}$

Relatively little of this has so far been reflected in investment law scholarship. As noted above, landmark disputes remain a popular subgenre. But even with respect to the major turning points, much remains clouded in mystery, and no systematic attempt so far has been made to understand the history of investment law through smaller, local events, such as specific investment projects, singular investment treaties, or more obscure episodes of investment dispute settlement. As for biographical scholarship, mainstream texts regularly note the formative role of individual figures, whether as drafters, negotiators or arbitrators - including the main drafter of the ICSID Convention and founding SecretaryGeneral of ICSID, Aron Broches, the American Commissioner on the

70 For influential examples see the Studien zur Geschichte des Völkerrechts published, since 2001, by Nomos (and offering biographical accounts of, amongst others, von Liszt, Schwarzenberger, Bluntschli, and Strupp); Jochen von Bernstorff, The Public International Law Theory of Hans Kelsen: Believing in Universal Law (Cambridge University Press 2010); Felix Lange, Praxisorientierung und Gemeinschaftskonzeption: Hermann Mosler als Wegbereiter der westdeutschen Völkerrechtswissenschaft nach 1945 (Springer 2017); and journal symposia, notably in the European Journal of International Law, offering biographical re-engagements with thinkers such as Lauterpacht, Kelsen, Scelle, and Schücking.

71 The Leiden Journal of International Law's decision to launch a 'periphery series' (assessing the work of, amongst others, Taslim O Elias and Alejandro Álvarez) is indicative: see the Editors' Introduction in (2006) 19 Leiden Journal of International Law 875. See further Becker Lorca (n 10).

72 Intriguing examples include Shynia Murase, 'Thomas Baty in Japan: Seeing Through the Twilight' (2003) 73 British Yearbook of International Law 315; or Katharina Rietzler, 'Counter-Imperial Orientalism: Friedrich Berber and the Politics of International Law in Germany and India, 1920s-1960s' (2016) 11 Journal of Global History 113.

73 Cf Matthew Craven's description of Koskenniemi's approach adopted in The Gentle Civilizer of Nations: Matthew Craven, 'Introduction: International Law and Its Histories' in Craven et al (n 3) 1, 12. 
United States-Mexico Claims Commissions, Fred K Nielsen, the founding fathers of the Abs-Shawcross Draft Convention, Hermann Joseph Abs and Lord Hartley Shawcross, or professor of international law and sole arbitrator in the Texaco oil concessions arbitration, René-Jean Dupuy, to name but a few. ${ }^{74}$ But authoritative biographies assessing their influence on international investment law remain scarce.

To state as much does not mean that historically informed scholarship in international investment law would have to become biographical, or focus more fully on (a broader range of) events. But it points to potential future directions and suggests that the turn to history may result in a more diverse, less predictable, and less doctrinally constrained, range of inquiries.

\section{B. History as Method: The Role of Primary Sources in Particular}

In another respect, the turn to history may require international investment lawyers to 'up their game'. In order to withstand the scrutiny of professional historians, research (whether looking at ideas, events or people, and whether working the broad canvas or zooming in on the minutiae) has to be done according to protocols that lawyers may not always be accustomed to.

At a basic level, this requires a commitment to objectivity ${ }^{75}$ - which may sit at odds with the almost naïve frankness of some legal scholars who 'plead guilty' to speculation about what might have occurred. ${ }^{76}$ At a

74 For comment on their influence see, for example, Christoph Schreuer et al, The ICSID Convention. A Commentary (2nd edn, Cambridge University Press 2009) 2 ('A. Broches ... as the ICSID Convention's principal architect'); Dolzer and Schreuer (n 1) 8 (underlining the initiatives of Herman Josef Abs); Julien Cantegreil, 'The Audacity of the Texaco/Calasiatic Award: René-Jean Dupuy and the Internationalization of Foreign Investment Law' (2011) 22 European Journal of International Law 441.

75 This is not to suggest that historical inquiries would reveal 'absolute, unchanging truths'. As Marc Trachtenberg, The Craft of International History: A Guide to Method (Princeton University Press 2006) 23 notes, while the Goddess History 'may be in possession of the truth ... to the historian she will at best "vouchsafe a glimpse. Never will she surrender the whole of her treasure. The most that we can hope for is a partial rendering, an approximation, of the real truth about the past"' (citing Pieter Geyl, The Use and Abuse of History (Yale University Press 1955) 62 et seq).

76 Pars pro toto, see Thomas W Wälde, 'The Specific Nature of Investment Arbitration' in Philippe Kahn and Thomas W Wälde (eds), Les aspects nouveaux $d u$ droit des investissements internationaux - New Aspects of International 
more operational level, a careful choice of sources and evidence becomes determinative. As Jason Yackee points out in his contribution to the present volume, '[o]ne of the defining features of the historical method is the use of "primary" sources, typically written documents housed in public or private archives'. ${ }^{77}$

Primary sources and their interpretation is what historians consider to be the most reliable evidence of past practices, events and ideas. ${ }^{78}$ Conversely, the failure sufficiently to study primary sources is one of the chief criticisms directed against lawyers engaging in 'history lite', which is said either to rely solely on secondary sources or to 'make a fetish of one or two famous primary sources, and consider [its] historical case made'.79 The existing historical scholarship in investment law is too diverse to be so classified, but Jason Yackee may have a point when noting 'the IIL community's unwillingness to engage in archival research'.80

Detailed work with primary sources comes with significant costs, in terms of accessibility, language, the need for travel, and the amount of time required to work in and with archives. Still, judging from the experience in other fields of international law, it is a worthwhile

Investment Law (Martinus Nijhoff 2007) 43, 67 (noting that his historical account of international investment law 'does ... not pretend to factual accuracy, but rather suggests a conceptual framework for a thorough review of the history of international investment law', that seeks to recount '[w] hat is likely to have occurred').

77 Jason W Yackee, 'The First Investor-State Arbitration? The Suez Canal Dispute of 1864 and Some Reflections on the Historiography of International Investment Law' (in this volume) 70, 78.

78 Hence Howell and Prevenier's reference to '[t]he archive ... [as] the historian's principal source of information': Martha Howell and Walter Prevenier, From Reliable Sources: An Introduction to Historical Methods (Cornell University Press 2001) 34.

79 Cf. Flaherty's general critique of historical scholarship written by lawyers (Flaherty (n 6) 553). For similar observations see Vadi (n 10) 9 (referring to the '[1]ack of consultation of primary sources' as one of the factors that 'make some of the histories of international law, as narrated by international lawyers, fundamentally flawed'); and Bederman (n 3) 46 (citing five 'key attributes of "law office history" [viz.] (1) a lack of analytic rigour in historical investigations, (2) selective use of historical materials, (3) sloppy or strategic methodologies in the review of historic sources, (4) overt or implicit instrumentalism in the selection of historic data and/or the conclusions drawn from such material, and (5) an unwillingness or inability to reconcile conflicting sources, or an inability to accept ambiguity or incompleteness in the historic record').

80 Yackee (n 77) 80. 
endeavour. If the turn to history has advanced our understanding of international law, then this to a significant extent is due to a greater willingness to work with primary sources - and to look more carefully at archives, at personal papers and the like. To give just two examples, patient work in the archives is behind the 'rediscovery' of the League of Nations in recent legal and historical scholarship, ${ }^{81}$ and a keen eye for de-classified documents has resulted in new insights on the role of international law in British foreign policy after World War II. ${ }^{82}$ It is very likely that the primary sources of investment law will yield similar insights: judging from the limited exploratory studies undertaken so far, government and company archives, or private papers of key actors are treasure troves of information about the evolution of investment law. But they need to be sought, and explored according to sound historical research methods. And indeed several of the chapters in the present book are based on an analysis of hitherto untapped historical sources. ${ }^{83}$

\section{Beyond Pragmatism: Reflective Uses of History}

Finally, a fuller engagement should lead investment lawyers to reflect consciously and critically on the uses of history. For the most part, existing investment law scholarship looks into the past to understand the present - and it seems to assume that this is the key reason for 'looking back'. This is particularly clear from much of the doctrinal work, such as

81 See, for example, Susan Pedersen, 'Back to the League of Nations' (2007) 112 The American Historical Review 1091, 1092 (suggesting that '[i]n contrast to a postwar historiography inclined to view the League from the standpoint of 1933 or 1939 , the relevant question [in contemporary research, benefiting, inter alia, from access to hitherto closed archives] is not "why the League failed" but rather the more properly historical question of what it did and meant over its twenty-five-year existence'); and further Susan Pedersen, The Guardians. The League of Nations and the Crisis of Empire (Oxford University Press 2015); Carole Fink, Defending the Rights of Others: The Great Powers, the Jews, and International Minority Protection (Cambridge University Press 2004).

82 See, for example, Anthony Carty, 'The Corfu Channel Case and the Missing Admiralty Orders' (2004) 3 The Law and Practice of International Courts and Tribunals 1; Anthony Carty, 'Distance and Contemporaneity in Exploring the Practice of States: The British Archives in Relation to the 1957 Oman and Muscat Incident' in Craven et al (n 3) 231; Charlotte Peevers, The Politics of Justifying Force: The Suez Crisis, the Iraq War, and International Law (Oxford University Press 2013).

83 See references below nn 100, 104-106 and accompanying text. 
that of Paulsson, Paparinskis and Weiler; ${ }^{84}$ their explicit or implicit premise is that the proper understanding of history points towards the correct understanding of contemporary standards of investment law. Such a 'pragmatic interest' 85 in legal history is a common feature of much historical scholarship in international law. According to Lesaffer, 'for most international lawyers their relation to history is a purely functional one. They look at history because they need it to better understand current issues and trends. ${ }^{86}$ But over time, this pragmatism may come under pressure. ${ }^{87}$

A fundamental concern is that to approach the past with a view to addressing contemporary concerns risks contorting the historical analysis and to fall prey to anachronism. ${ }^{88}$ It tends to invent linkages and to see the past 'not in terms of what it was' but 'in terms of similarities with or differences from the present'. 89 In this perspective, 'genealogical' or 'evolutional' histories are criticized for 'sin[ning] against the most basic rules of historical methodology,' namely to study 'history' first and foremost 'in its own right': 'let the past be past - at least as far as this is humanly possible'. ${ }^{90}$

See above nn 33-44 and accompanying text.

85 Lesaffer (n 4) 33.

86 ibid.

87 Lesaffer, ibid 34, dismisses the "amateurism" of international lawyers', but warns 'professional legal historians ... not [to] gloat over [it]', as they themselves had 'disdained to plough the field'. Vadi (n 10) 8-9 sees the history of international law as a 'battlefield' and suggests that 'a turf war has erupted between "historians" and "lawyers" on what kind of history of international law we could and/or should have'. Both statements imply neat disciplinary distinctions, which may not reflect the diversity of approaches adopted by international lawyers, legal historians, and professional historians.

88 This echoes the concerns of Quentin Skinner, 'Meaning and Understanding in the History of Ideas' (1969) 8 History and Theory 3 about 'tracing' and causality in the history of ideas. To Skinner, it was misplaced to 'stud[y] the history of ideas in the attempt to learn directly from the classic authors by focusing on their attempted answers to supposedly timeless questions' (ibid 51); instead, in Skinner's view, the historian should only focus on what the author of a text 'in writing at the time he did write for the audience he intended to address, could in practice have been intending to communicate by the utterance of this utterance' (ibid 49).

89 Lesaffer (n 4) 35.

90 ibid 34 and 37-38. Vadi (n 10) makes a similar point: according to her, many 'legal historians consider that the past should not be read as a mere precursor of the present and are wary of genealogical frameworks' (ibid 10). 
Most international lawyers engaging with the past have not accepted such a constraint. The bulk of historically informed international legal scholarship copes with the problem of anachronism and views 'law and history as necessarily entangled' ${ }^{91}$ Even so, the historiographical turn in public international law has prompted reflection on the proper uses of history, and may have forced international lawyers to avoid the facile claims of continuity. ${ }^{92}$ Some scholars have justified the 'functional' use of history by pointing to the particular nature of law. Hence, Anne Orford sees law as a discipline 'in which judges, advocates, scholars and students all look to past texts precisely to discover the nature of the present obligations' and where 'law relies upon precedent, customs and patterns of argument stretching back, at least in the common law tradition, from as recently as yesterday to "time immemorial.", 93

At the same time, historical scholarship arguably has been most influential as an instrument of critique, a critique that, in Martti Koskenniemi's words, can make 'the voice of the past' heard, but also seek to 'attain a better understanding of the nature of the present' ${ }^{94}$ Such critical approaches, almost inevitably drawing on historical inquiries, have enriched our understanding of concepts, events and protagonists of international law, but above all laid bare its biases. To name but a few,

91 Vadi (n 10) 17 (distinguishing between 'diachronic' approaches that 'stud[y] legal phenomena as they change in the long term' and 'synchronic' scholarship that 'investigates legal issues as they exist at one point in time without reference to their evolution').

92 See, for example, George Rodrigo Bandeira Galindo, 'Force Field: On History and Theory of International Law' [2012] Rechtsgeschichte - Legal History 86, 93 (pointing out that '[w]hat is necessary, however, is that any international lawyer - practitioner or theorist alike - approach history more carefully, avoiding seeing in the past what is not there at all: the present').

93 Anne Orford, 'On International Legal Method' (2013) 1 London Review of International Law 174. Reviewing recent writings on the history of international human rights law, Philip Alston makes a similar point when referencing the 'strong genealogical or ancestral component' in the language of international law and noting that 'one generation has provided the foundation or the impetus for the emergence and shaping of the next generation's usage'; Philip Alston, 'Does the Past Matter? On the Origins of Human Rights' (2012) 126 Harvard Law Review 2043, 2052.

94 Martti Koskenniemi, 'Histories of International Law: Significance and Problems for a Critical View' (2012) 27 Temple International \& Comparative Law Journal 215, 230. 
historical research has informed criticism of international law's Eurocentric and imperial legacies ${ }^{95}$ (just as much as it may pose questions 'to those who seek to disparage international law as a purely Eurocentric imperialist project' $\left.{ }^{\prime 6}\right)$. By the same token, critical approaches questioning the assumption that international law is a force for good draw on historical inquiries undermining the all-too-facile progress narratives. ${ }^{97}$

All of these concerns apply to international investment law as much (if not more) than to any other branch of public international law. And yet few of the questions and concerns just summarized are reflected in the existing investment law literature. The debate about anachronism, for example, has not seriously been taken up in the discipline. Similarly, with few exceptions (Kate Miles' study prominent among them), ${ }^{98}$ the critical potential of historical research has yet to be realized. Again, just as with respect to the focus and method of historical scholarship, international

95 Influential accounts include Anthony Anghie, Imperialism, Sovereignty and the Making of International Law (Cambridge University Press 2004); Anand (n 10); Chittharanjan F Amerasinghe, 'The Historical Development of International Law - Universal Aspects' (2001) 39 Archiv des Völkerrechts 367; Berman (n 66). For clear analyses, see Arnulf Becker Lorca, 'Eurocentrism in the History of International Law' in Fassbender and Peters (n 10) 1034-1056; and Emmanuelle Jouannet, 'Des origines coloniales du droit international: A propos du droit des gens moderne au XVIIème siècle' in Dupuy and Chetail (n 10) 649. In their introduction to the Oxford Handbook, Fassbender and Peters (n 61) 2 state laconically: 'The Eurocentric story of international law has proven wrong because it is incomplete'.

96 Marcus M Payk, 'The History of International Law - or International Law in History? A Reply to Alexandra Kemmerer and Jochen von Bernstorff' EJIL:Talk!, 8 January $2015<$ www.ejiltalk.org/the-history-of-international-lawor-international-law-in-history-a-reply-to-alexandra-kemmerer-and-jochen-vonbernstorff/> accessed 30 August 2017.

97 See Tilmann Altwicker and Oliver Diggelmann, 'How Is Progress Constructed in International Legal Scholarship?' (2014) 25 European Journal of International Law 425 (observing that ' $[\mathrm{t}]$ he idea of progress is omnipresent in international legal discourse'). Similarly, Alston (n 93) 2063 (observing that 'international law scholars have long been accused of portraying their discipline as an intrinsically or inexorably progressive one'). For a particularly influential example see Manley O Hudson, Progress in International Organization (Stanford University Press 1932). For a critical analysis see Thomas Skouteris, The Notion of Progress in International Law (TMC Asser Press 2011); Payk (n 96) pointedly observes that 'those who see international law as a force for good per se and who are interested only in tracing the success story of its development will have little appreciation for detailed contextualisation'.

98 See above nn 54-58 and accompanying text. 
investment law would greatly benefit if it opened up towards the broader debates triggered by the historiographical turn in public international law.

\section{THE DIVERSITY OF HISTORICAL INQUIRIES: THE CONTRIBUTIONS TO THIS BOOK}

The preceding overview illustrates the ubiquity of historical arguments in investment law and practice, but also suggests that the discipline's turn to history is at an early stage. Above all, it has outlined implications and consequences of seriously engaging with history, and identified potential avenues for future research. The contributions to the present book do not explore all these avenues: as noted above, this book is an ouverture, not a definitive treatment. But they offer reflections on the conditions, methodological possibilities, benefits, and challenges of engaging in historical research and historical argument. Heterogeneity of approaches is intended, as international investment law scholarship stands to gain from greater diversity. As a consequence, the book purposefully features a wide range of inquiries. Biographical studies feature alongside histories of key events and institutions; both macro- and micro-studies are presented.

Seeking to avoid the charge of 'history lite', many chapters heavily rely on primary sources - which offer new perspectives on, for example, the settlement of individual historical disputes, the influence of individuals on the shaping of contemporary investment law, and the practice of states in negotiating treaties and defending economic interests of their nationals. As importantly, the contributions go beyond the pragmatism characteristic of much of the existing scholarship and reflect on the proper uses of history: unsurprisingly, contributors adopt diverging approaches, but crucially, all appreciate the need for reflecting on the use and function of historical approaches, on methodology and its challenges.

Given the diversity of approaches taken and the breadth of issues addressed in the contributions to the present book, providing a structure to the presentation is difficult and necessarily somewhat arbitrary. But choices have to be made: what seemed best is to group the contributions to the present book according to two major themes they address. The first theme, presented in Part II of the book, relates to the different objects and objectives of historical analysis in international investment law. This Part groups contributions whose principal focus is on the question of what it means when engaging in historical analysis in international investment law, what to look at, and why, for which purposes, we engage in 
historical endeavours. These questions are central to understanding history as a method and reflecting critically on it (A.).

The second set of contributions, which are included in Part III of the book, tends to focus on questions of methodology and their challenges. The contributions in that Part exemplify different methodological approaches to historical analysis, such as studies of state practice, biographical studies and studies in political history, and address both the benefits of and the challenges to such studies. Approaching methodology in the set-up of historical research is key for giving way to a truly historiographical turn in international investment law (B.).

\section{A. Objects and Objectives of History}

Part II opens with a chapter by Andreas Kulick, who discusses the impact of the linguistic turn on historical analysis. ${ }^{99}$ It shows that history is, at its core, a social construction of the historian in the form of a narrative about historical events and ideas; a product of the historian's presentation of what she conceives as the result of her historical research. Her conception, in turn, is influenced not only by the methodological approach and the object analysed, but also by the epistemic context, the professional socialization, and the political preferences of the historian concerned. As Kulick shows, a scholar socialized in public international law who is supportive of the present investment regime will likely construct quite a different historical narrative about international investment law than a domestic public lawyer who is critical of the regime. Similarly, the choice of historical method, object of study and research question may depend on the professional, epistemic and ideological stance of the historian in question. What flows from Kulick's analysis is that every historical inquiry has to be viewed in the context of the hermeneutic, ideological, or other preconceptions of the historian and the objective(s) she pursues. This, in turn, is one important aspect of approaching historical analysis in international investment law in a reflective fashion.

Reflections on the purposes of engaging in historical analysis are also central to the contributions that follow in Part II of the book. They bring out that historical analysis can have multiple purposes, depending on the context in which history is used as a method and depending on the approach the historian is taking. An important distinction is introduced

99 Andreas Kulick, 'Narrating Narratives of International Investment Law: History and Epistemic Forces' (in this volume) 41. 
by Jason Yackee who distinguishes between two types of historical studies with different objectives: one, which he calls 'origins studies', seeks to establish where a specific rule, principle, institution, or idea about the law comes from; the other, which he terms 'understanding studies', aims at understanding a historical text or fact in its historical context. ${ }^{100}$ With respect to both, Yackee argues that investment law scholars can 'do' history better than they currently do. Above all, historically minded investment law scholars should, Yackee argues, have a better sense of the issues, both epistemological and practical, that professional historians wrestle with, and need to be more comfortable with engaging in primary-source-based, rather than secondary-sourcebased, analysis. To illustrate how such research can be conducted in the context of an origin's study, Yackee draws on his research into an investor-state dispute from 1864 involving the Suez Canal Company and Egypt that was resolved through a process we would today classify as investor-state arbitration.

Heather Bray focuses on another objective of history. Rather than trying to locate the origins of a particular legal rule, principle or idea, she argues that historical analysis can have the purposes of describing and understanding legal change over time. ${ }^{101}$ Analysing the change in investment dispute settlement from institutionalized international claims commissions, beginning in 1794 with the signing of the Jay Treaty, to modern investor-state arbitration, she contests that investment law's history can be rooted in one concrete event that, comparable to a big bang, has brought about the present-day system. Instead, every component that is characteristic for modern investment law, she argues, builds on some earlier experience or idea. Historical analysis can therefore only ever present parts of a continuum of events and should thus be looked at through the prism of evolution, in order to understand change and the role of human agency in that change. At the same time, Bray insists that the observance of change has to be separated strictly from its normative assessment as positive (that is, 'progress') or negative (that is, 'regression'). Such an assessment, she points out, is the product not of historical, but of normative analysis. This distinction between historical assessment and normative assessment is key for a reflective use of history - and those making use of historical arguments should conceptually distinguish both dimensions.

$100 \quad$ Yackee (n 77) 70.

101 Heather L Bray, 'Understanding Change: Evolution from International Claims Commissions to Investment Treaty Arbitration' (in this volume) 102. 
Kate Miles' chapter turns to yet another use of history, namely to serve as an instrument of criticism of the present state of the law, its institutions and practices. ${ }^{102}$ She adopts a historical approach to international investment law as an instrument of critique and argues that the value of such an approach consists in creating new understandings of historical periods, in illuminating the condition of modern international law, and in opening up room for critique of the law as it stands. Building on the tradition of TWAIL, Miles' chapter argues that international investment law has colonial origins and has served and continues to serve as an instrument of hegemony. Yet, rather than focusing on historical facts, she unveils the colonial, imperial and hegemonic character of international investment law, both past and present, through the prism of concepts and language. For this purpose, she examines notions of property, control, the law of nations, warfare, violence, and 'lawlessness' in the writings of early scholars such as Vitoria, Grotius, and Vattel, and their echoes in international law in subsequent centuries. It is against this backdrop, that Miles reflects upon the language that surrounds the modern framework for the protection of foreign investment, the language that emerges in the discourse and in the justification of investment treaties in place, and the assumptions that lie at the core of international investment law in the 21st century. In her view, modern practices continue to be influenced by historical ideas and should be changed if investment law is to fully emancipate itself from what Miles views as a problematic history.

In the final chapter of Part II, Jörg Kammerhofer presents a critical view vis-à-vis the use of historical analysis as a tool of criticism. ${ }^{103}$ Addressing the relationship between legal history and the nature of international investment law as positive law from a legal theory perspective, he fears that the use of history for criticizing the present state of the law may undermine the 'autonomy of legal scholarship', which he sees as being built on legal doctrine, not politics. In Kammerhofer's view, the history of law may be an important reservoir of doctrinal argument and may even be able to serve as a critical tool in understanding doctrinal concepts and ideas. But historical arguments should not, in his view, be used for purely political purposes. For him, this would be an abuse of history and historiography in legal argumentation.

102 Kate Miles, 'History and International Law: Method and Mechanism Empire and "Usual” Rupture' (in this volume) 136.

103 Jörg Kammerhofer, 'The Challenges of History in International Investment Law: A View from Legal Theory' (in this volume) 164. 
As the contributions in Part II show, a more reflective approach to historical analysis will inevitably lead to the need of those who use historical arguments and embark on historical research in international investment law to query and lay open the purposes of that endeavour and to reflect on the interaction between history and politics. While entirely objective historical inquiries may face great difficulties, reflection on these issues illustrates that attention needs to be paid to the hermeneutic, ideological, political and other preconceptions of the historian and to the purposes of her historical analysis. This is an important part of reflecting critically on the use of historical inquiries and its objectives and going beyond pragmatism as outlined above.

\section{B. Diversity of Methodological Approaches and Methodological Challenges}

Part III of the book then turns its focus to different methodological approaches to doing historical research. The contributions in this part illustrate not only the manifold ways of doing history we call on above, they also show the value of and need for critical reflection on questions of methodology and research design, particularly regarding the use of primary sources.

Part III opens with Mona Pinchis-Paulsen's investigation, based on in-depth archival research, of the meaning and development of FET clauses in post-war US commercial treaties. ${ }^{104}$ This research shows how the archival material uncovered can help to shed light on the thinking of one of the most influential treaty-making powers on a central, but also controversial investment treaty standard. Furthermore, Pinchis-Paulsen uses her historical research as a case study to illustrate three methodological challenges that any researcher must address when investigating the history of international investment law. First, Pinchis-Paulsen addresses the challenge of periodization; that is, whether historical research can and should be divided into explicit time periods. Periodization may present a dilemma: while helpful, perhaps even indispensable, as a device to structure historiographical work, periodization entails the risk of creating artificial constructions.

Second, Pinchis-Paulsen addresses the challenge of embedding historical facts in their social, economic and political context. This not only helps to provide the necessary backdrop for the functioning of law as a

104 Mona Pinchis-Paulsen, 'Resolving Challenges to Historical Research: Developing a Project to Define Fair and Equitable Treatment' (in this volume) 179. 
social institution, but also increases the scope of historical research. Finally, Pinchis-Paulsen offers practical advice on how to deal with the problem of anachronism, namely by organizing historical inquiries into two stages: first, by analysing the past as past, without any reference to the present, and second, by putting historical evidence into a wider comparative context that may include the present state of the law. That way, Pinchis-Paulsen opines, learning from the past about the present is possible.

Jean Ho turns to a different aspect that illustrates how in-depth studies of archival material can help us to better understand and theorize about the state of present-day international investment law, namely when it comes to the protection of contractual obligations under investment treaties. ${ }^{105}$ She points out that, while it is often acknowledged that the modern regime of investment protection evolved from the state-directed regime of diplomatic protection, little attention has been paid to the diplomatic history of contractual protection. Yet, this history can help, Ho argues, to shed light on why contemporary arbitral tribunals are resistant to equating simple breaches of investor-State contracts with the violations of investment treaty standards, such as an umbrella clause or the FET standards. While not satisfactorily explained by treaty language, this resistance can, Ho argues, be linked to the restrictive practice of states to exercise diplomatic protection for breaches of contract.

Drawing on extensive research in the diplomatic archives of France and the United Kingdom to substantiate that claim, Ho also provides reflection on the methodological choices she made. Given the fact that archival research is labour-intensive and may yield little innovative insights if the archives in question do not contain sufficient relevant material, Ho urges that considerations of effectiveness must be taken into account in research design. Similarly, the language abilities of the researcher and the accessibility of archives housing diplomatic documents are important factors to weigh. In light of limited time to spend on researching a specific historical question, the research question and methodology should, in her view, be limited to documents whose language the researcher is able to understand and to archives that are accessible without undue difficulty. While a more comprehensive approach both in terms of language and in terms of archival material

105 Jean Ho, 'The Evolution of Contractual Protection in International Law: Accessing Diplomatic Archives, Discovering Diplomatic Practice, and Constructing Diplomatic History' (in this volume) 213. 
would be desirable, limitations are methodologically defensible, but have to be acknowledged explicitly.

Yuliya Chernykh's chapter illustrates another methodological approach available to researchers of the history of international investment law. ${ }^{106}$ Making use of his personal archives, she traces the influence of Sir Elihu Lauterpacht in the 1950 s on shaping core elements of international investment law through his activities as counsel in settlement negotiations concerning the Anglo-Iranian Oil Company case in 1953-1954 and his involvement in the drafting of the 1959 Abs-Shawcross Draft Convention on Investment Abroad. Through this biographical approach, Chernykh shows that Sir Elihu was responsible for bringing the idea that individual investors have access to dispute settlement under international law directly against the state into the Abs-Shawcross Draft Convention. While never hardening into binding treaty law, the Draft Convention nevertheless influenced the development of model investment treaties and thereby influenced modern investment law.

Chernykh's method allows us to develop a better understanding of investment law through the eyes of an important participant in the policy process during the field's foundational period. Going further, she even suggests that certain individuals, rather than institutions, were at the forefront of developing the legal principles that govern international investment relations and investment dispute settlement today. The key to this conclusion lay in the unpublished archives of the late Sir Elihu Lauterpacht that Chernykh analysed and molded into a convincing historical argument.

Taylor St John's chapter that follows demonstrates how historical approaches to investment law not only improve our ability to interpret international investment treaties and to better understand how their content emerged, they also provide invaluable insights into the functions of law and institutions in the field of international investment law. ${ }^{107}$ Her chapter focuses on political history, and in particular on how historical approaches help to shed light on the political context in which a particular treaty (or law) was made, or an international institution established. Using the creation of ICSID as an example, St John shows that the drafting of a treaty and the creation of an international organization for the settlement of investment disputes requires more than

106 Yuliya Chernykh, 'The Gust of Wind: The Unknown Role of Sir Elihu Lauterpacht in the Drafting of the Abs-Shawcross Draft Convention' (in this volume) 241.

107 Taylor St John, 'Enriching Law with Political History: A Case Study on the Creation of the ICSID Convention' (in this volume) 286. 
simply technical expertise. Instead, having visions that can gather state support and strategies for the successful implementation of the resulting texts are key.

The ICSID Convention perfectly illustrates how the visions of certain individuals at the World Bank - notably that of Aron Broches and his idea to focus only on the settlement of disputes - rather than on drafting a convention encompassing substantive standards of treatment, laid the basis for one of investment law's foundational treaties. Moreover, the strategies Broches and the World Bank developed for the Convention's successful adoption - principally by using a consultative, organizationdriven, rather than a deliberative, state-driven procedure for drafting were crucial for securing broad consensus among states in the politically heavily contested field of foreign investment law. St John's political history of the emergence of the ICSID Convention brings these historical facts to life, and reasserts the benefits to be gained from a thick contextualization of primary sources.

In the final chapter, Muin Boase addresses, from a historical perspective, blindspots in the current system of international investment protection, by focusing on investor duties. ${ }^{108}$ Drawing on Foucault's genealogical approach, he addresses how previous generations of lawyers and law-makers conceived of the scope of duties of foreign merchants under international law. Boase, inter alia, analyses the conditions under which home states could be held responsible for injuries caused by their nationals under customary international law during the 18th and 19th centuries, and how they were required to prevent harmful activities of their merchants abroad, such as corruption, and punish them in case of breach. Boase also analyses the practice of states of refusing to exercise diplomatic protection if their nationals engaged in 'censurable conduct' abroad.

All of these instances, Boase argues, were based on the idea that states not only had the responsibility to protect foreigners, but could also incur responsibility for the actions of their citizens abroad. Yet, when modern investment treaty law was created, through the conclusion of bilateral investment treaties and of the ICSID Convention, the responsibility of host states for the treatment of foreign citizens was vested as rights of foreign investors, but the responsibility of home states for the conduct of their nationals abroad was not internationalized as duties of foreign investors. Criticizing this one-sided state of investment law, Boase

108 Muin Boase, 'A Genealogy of Censurable Conduct: Antecedents for an International Minimum Standard of Investor Conduct' (in this volume) 321. 
concludes by suggesting that based on his historical analysis the idea could be developed that customary international law contains not only a minimum standard of treatment of aliens, but also a minimum standard of conduct foreign investors have to abide by, namely not to engage in 'censurable conduct'. Boase's chapter is therefore not only an example of how historical analysis can be used as a source of critique of the present state of investment law. He goes further and makes use of the recognized sources of international law in order to suggest that historical precedent can be used to argue for the existence of duties of foreign investors as part of customary international law and thereby change the current state of the law from within.

While far from exhaustive, the contributions in Part III of the book address various historical methods for dealing with primary sources; some even deal with so far entirely unstudied documents. The contributions illustrate the great methodological diversity that is possible in historical research in international investment law and deal with a number of challenges and pitfalls. They should provide inspiration to uncover the many other untapped archival sources and to draw up, step-by-step, a more comprehensive and deeper appreciation of investment law's history.

\section{CONCLUSION AND OUTLOOK}

The history of international investment law still has many blindspots. This is all the more reason to engage with it, to take it seriously, and to unlock it. The present book can be no more than a start in this endeavour: As an appetizer, it hopes to offer a taste of what reflective uses of history can offer; as an ouverture, it seeks to generate sensitivity for the difficulties reflective approaches to historical argument in international investment law entail. Yet, as the present introduction has shown, a serious engagement with the history of international investment law does not need to start from scratch, as historical arguments are already widespread. Still, there is an urgent need for a deeper reflection on how investment lawyers "should "do" history', 109 and for a debate about "best practices" for structuring and conducting the production of historical research' ${ }^{110}$ This debate will require investment lawyers to be prepared to learn from professional historians and in many instances to move out

\footnotetext{
109 See Bederman (n 3) 44.

110 Yackee (n 77) 78.
} 
of their methodological comfort zone. What is needed, in short, is a real turn to history in the field.

The contributions to the present book aim to help lay the groundwork for such a real turn. They illustrate different methodological approaches towards solid and innovative historical research that avoid the pitfalls of nonreflective historical analysis. They shed light on, and elucidate, legal rules and principles of present-day investment law - which for most investment lawyers is likely to remain the primary reason for turning to historical analysis - just as they will allow us to critically assess the current state of the law and imagine alternatives. And they can also be used as examples when tackling other research questions in international investment law from a historical perspective.

As editors, we hope that this groundwork will inspire other authors lawyers, historians, and social scientists, of diverse disciplinary backgrounds - to engage with the history of international investment law in their research, and to do so based on well-reflected methodological premises. As the contributions to the present book illustrate, methodologically sound historical research has considerable potential for enriching and deepening our understanding of international investment law.

What is more, methodologically sound historical research into international investment law could also help fill what so far remains a surprising gap in the historical analysis of public international law more generally. Notwithstanding its richness and diversity, too much of the historically informed scholarship in public international law remains focused on the great questions of war and peace, on statehood and empire, on treaties and sources. ${ }^{111}$ The contributions to this book suggest that there is much to find in, and much to learn from, the history of international economic law, from studying commercial relations and commercial treaty-making between states and other actors. ${ }^{112}$ For this

111 As an example, the history of commercial treaties is mentioned briefly in Fassbender and Peters (n 61) 12 (stating that "international legal historiography treated wars and treaties as the most significant "event". The treaties attracting particular interest were treaties of alliance, seeking to forestall war, on the one hand, and peace treaties, on the other hand. As a third group, treaties of commerce can be mentioned'), but does not reappear in the Oxford Handbook as a point of in-depth analysis.

112 For studies in this direction see Martti Koskenniemi, 'The Political Theology of Trade Law: The Scholastic Contribution' in Ulrich Fastenrath et al (eds), From Bilateralism to Community Interest: Essays in Honour of Bruno Simma (Oxford University Press 2011) 90; Martii Koskenniemi, 'Empire and International Law: The Real Spanish Contribution' (2011) 61 University of Toronto Law Journal 1. 
reason, we hope not only that the history of international investment law can serve to enrich our understanding of the history of international economic law and commercial-treaty making. Much more: we hope it can contribute to the development of a more comprehensive economic history of international law, thus moving the analysis of international economic law from the periphery towards the centre of international legal historiography. 
Stephan W. Schill, Christian J. Tams, and Rainer Hofmann - 9781786439963 Downloaded from PubFactory at 04/26/2023 10:32:49AM via free access 